\title{
The 1986 National Forest Congress "Canada's Forests: Commitment to the Future"
}

by

\author{
R.J. Bourchier ${ }^{1}$
}

April 8, 9 and 10, 1986 saw over 400 delegates assemble at the Skyline Hotel in Ottawa to analyze and discuss the future of the forest sector of the Canadian economy. The event was sponsored by the Canadian Forestry Association with co-sponsorship by the provincial and federal forestry ministers, the Canadian Institute of Forestry, the Canadian Forest Industries Council, the Canadian Pulp and Paper Association, wood lot owners associations and the forestry schools of Canada.

The Congress was chaired by CFA President Chuck Geale and he of course was assisted in preparing for the Congress by a hard working Steering Committee and a Program Committee chaired by Dr. Gilbert Paillé, Associate Deputy Minister of Quebec's Ministry of Energy and Resources. I had the honour to chair a local arrangements team that worked hard under Logistics Committee Chairman Bert Joss of CPPA.

There were some notable events and firsts. The Prime Minister, the Right Honourable Brian Mulroney, opened the Congress and spoke at some length about the importance of the nation's forests and his Government's strong commitment to improving forestry stewardship. He noted that he had made good on his election promise "to raise forestry to full Cabinet status." Granted this is not quite the same as what many people thought the promise was - "full Departmental status", but few would say it was not a useful step, particularly in light of the appointment of the very dedicated and hard working Gerry Merrithew as Minister of State for Forestry. To my knowledge this is the first time a Canadian Prime Minister has addressed an all-forestry gathering since 1906 when Sir Wilfrid Laurier spoke to the first Forestry Congress in Montreal

The program was organized around four sessions and themes: Trade - Can Canada Compete?; Wood Supply - A Growing Concern; Jobs - Security or Survival; Environment and Multiple Use - Protecting a Heritage. A fifth session focussed on the conclusions that could be drawn from the Congress and the four forestry forums that had been organized by the Canadian Council of Forestry Ministers in the months preceding the Congress.

The session on trade was to have been moderated by the Prime Minister, but as so often happens with politicians, other business proved more pressing and the Hon. Gerry Merrithew

$\overline{1 E x e c u t i v e ~ D i r e c t o r, ~ C a n a d i a n ~ I n s t i t u t e ~ o f ~ F o r e s t r y ~}$ acted as moderator and did a good job. The panel included the Hon. James Kelleher; W.S. Merkin, Deputy Assistant US Trade Representative for Canada; the presidents of Abitibi-Price, McMillan Bloedel, the Canadian Paperworkers, the CPPA, and Normick-Perron Inc., Messers Koken, Smith, Buchanan, Hart and Perron respectively. Several conclusions emerged: Canada is losing its share of world forest products markets and steps must be taken to improve the country's ability to compete. Some of the recommended steps were: a bilateral trade agreement with the United States; tax changes to allow transfer of capital cost allowances and hence better profitability; grants to industry to be replaced with a nondiscriminatory tax-based incentive system; governments to ensure that taxation in Canada is competitive with the U.S.; competition policy to be revised to allow for product specialization and export consortia; and finally, allow the Canadian dollar to float. The wrap-up Speaker was Mike Apsey of COFI.

The second session focussed on wood supply and was moderated by R.J. Kneeland, President and CEO of Kruger Inc. Participants included Professors Reed, Baskerville, Weetman and Pearse, the president of Fraser Inc., J.N. Bowersock, the Alberta Deputy Minister F.W. McDougall, Consolidated Bathurst President Oscar Strangeland and Manuel Werner, an economist from the Royal Bank. The main conclusions were: adequate forest management requires that better means be devised to set social and economic priorities so that governments and industry will see clearly the need to invest in future fibre supplies; federal-provincial agreements provide a good means to fund forest management but other additional mechanisms should be sought with emphasis on continuity and long term commitment; tenure of forest land is fundamental to forest management and should be long-term, area-secured, subject to regular review with public consultation and include procedures for auditing silvicultural results; wood allocation should be de-politicized and give due consideration to the role of private woodlots; forest protection against weeds, pests and fire is a fundamental part of forest management; good silviculture will require a better data base and consideration should be given to making silvicultural certification a requirement under federal-provincial forestry agreements. The wrap-up speaker was J.C. Mercier, Associate Deputy Minister of the Canadian Forestry Service.

The second day of the Congress opened with the session on jobs moderated by the outspoken West Coast personality Jack Webster. Participants were Adam Zimmerman, President of Noranda; Jack Munro of the I.W.A.; Graham 
Bruce, mayor of North Cowichan; Columnist Doug Fisher; and Dian Cohen. The speakers re-iterated the importance of the sector in generating employment and concluded that: labourmanagement relations must be improved; labour mobility and training programs needed improvement; seasonality of work opportunity needs to be reduced and employment programs must concentrate on asset creation. The Honourable Flora MacDonald was wrap-up speaker and I thought did a poor job. It sounded like a canned speech ready for delivery to Parliament. She even addressed us as "members" at one point!

The fourth session with its focus on environment and multiple use was moderated by the President of Lakehead University, Robert Rosehart. Participants were: BC Chief Forester John Cuthbert; Ontario's top forestry official, Ken Armson; Jack Ward Thomas, Chief Research Wild life Biologist of the US Forest Service; Bert Gayle of Canadian Forest Products; Verna Ledger of the IWA; Gregg Sheehy of the Canadian Nature Federation and Rich Goulden of the Manitoba Department of Natural Resources. Bill Young of the BC Forestry Association provided the wrap up. The conclusions reached were: means must be developed to resolve crippling conflicts over forest land use; appropriate legislation, public participation and zoning are all useful tools in conflict resolution and avoidance; more research is needed on the impact of pollution on the forest; and pesticides must be recognized as an essential tool of forest management.

Running through all the deliberations were some common concerns and views: education, training and technology transfer need more attention; research and development are key items and must be focussed on real needs; public participation is most important and must be seen to be open and genuine; a cohesive "National Game Plan" involving industry, governments, labour and public is required to further progress in forest management for the benefit of future Canadians.

The fifth session was unique. After a masterful summary by Program Chairman Gilbert Paillé, a very special panel took the stage moderated by television's Pamela Wallin. The panelists were Canada's Forestry Ministers who openly discussed the forestry issues raised during the congress and responded to questions put forward by delegates. That has never happened before and I thought it a good omen for the future.

I think the Congress was a success. It got reasonably good press coverage. A good sampling of non-forestry people participated fully both formally and informally and politicians were much in evidence. Events like this seldom produce dramatic break-throughs. They are important though in raising the consciousness of the public and their leaders to the importance of good forestry and they provide periodic documentation and reference points on the road to responsible forest resource management. They are not a substitute for the daily and weekly efforts of all forestry people to ensure that Canadians make the wise forest resource decisions that are required now and in the future.

The proceedings of this congress will be published in English in The Forestry Chronicle and in French in Forêt Conservation. Watch for them - you'll find some interesting information and ideas.

\section{Retired Members}

This note is to remind retired members and Section Councils about the provisions of By Law 4.4 which allows individuals who have been Institute members for 15 or more years and who retire "with a substantial reduction in income" to apply for retired status. If approved, retired status members are not required to pay any dues, but retain all rights and benefits except receipt of The Forestry Chronicle. The Chronicle is available to retired members on payment of the regular subscription rate for individuals (\$28.00 for 1986).

The proper procedure for those interested in this provision is to apply to your Section Council. Councils will deal with these applications and notify National Office of the decision so that records can be adjusted.

\section{R.J. Bourchier}

Executive Director 